\title{
Comparison and Assessment of Factors Affecting the COVID-19 Vaccination in European Countries
}

\section{Porównanie i ocena czynników wpływających na szczepienia przeciw COVID-19 w krajach europejskich}

\section{Serhii Kozlovskyi*, Daria Bilenko**1, Mykhailo Kuzheliev**2,

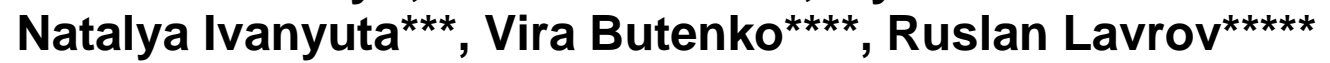

\author{
*Department of Entrepreneurship, Corporate and Spatial Economics, \\ Vasyl' Stus Donetsk National University, Vinnytsia, Ukraine \\ E-mail: s.kozlovskyy@donnu.edu.ua,ORCID:0000-0003-0707-4996 \\ **Department of Finance named after L.l. Tarangul, \\ University of State Fiscal Service of Ukraine, Irpin, Ukraine \\ ${ }^{1}$ E-mail: belenkodaria1@gmail.com,ORCID:0000-0002-6220-8101 \\ ${ }^{2}$ E-mail:nni_fbs@ukr.net,ORCID: https://orcid.org/0000-0002-7895-7879 \\ ***Department of Civil, Labour and Social Security Law, Donetsk Law Institute \\ of the Ministry of Internal Affairs of Ukraine, Mariupol, Ukraine \\ E-mail: natalaivanuta9@gmail.com, ORCID: https://orcid.org/0000-0001-9177-9280 \\ ****Department of Economic Theory, National University of Life and \\ Environmental Sciences of Ukraine, Kyiv, Ukraine \\ E-mail: butenkovera@nubip.edu.ua,ORCID: https://orcid.org/0000-0001-8814-9392 \\ ***** Department of Finance, Accounting and Taxation, \\ PHEI European University, Kyiv, Ukraine \\ E-mail: lavrus2017@gmail.com, ORCID:0000-0002-9655-4467
}

\begin{abstract}
The Covid-19 spread has become a major challenge for humanity in the last decade. It was believed that the Covid19 vaccine development would have to end the pandemic. On the contrary, society has faced a new challenge which is that there are both countries that cannot afford to purchase the Covid-19 vaccine and inhabitants who do not trust new vaccine. Without adequate Covid-19 vaccination level, the global pandemic is not going to end. The object of this study is factors affecting the vaccination Covid-19 in European countries. The subject of the study is the statistical analysis methods to compare and assess of factors affecting the vaccination Covid-19 in European countries. The aim of the study is to find out which concerns about vaccination are more important and have an impact on the Covid-19 vaccination level in European countries. It is examined six factors; three of them relate to the government vaccine administration, the other three are about a public opinion on Covid-19 vaccination. The analysis is carried out in 22 European countries. The result of the study allows to state that public opinions factors are more important in pandemic and have more impact on the vaccination rate.
\end{abstract}

Key words: Covid-19 (Coronavirus) pandemic, government vaccine administration, public opinions, regression data analysis

\section{Streszczenie}

Rozprzestrzenianie się Covid-19 stało się głównym wyzwaniem dla ludzkości. Wydawało się, że opracowanie szczepionki przeciw Covid-19 zakończy pandemię. Tymczasem społeczeństwa stanęły przed nowym wyzwaniem polegającym na tym, że są zarówno kraje, których nie stać na zakup szczepionki Covid-19, jak i mieszkańcy krajów, które na nią stać, a którzy nie ufają nowym szczepionkom. Bez odpowiedniego poziomu szczepień przeciwko 
Covid-19 globalna pandemia szybko się nie skończy. Przedmiotem badań są czynniki wpływające na szczepienia Covid-19 w krajach europejskich. Wykorzystano metody analizy statystycznej w celu porównania i oceny czynników wpływających na szczepienie Covid-19 w krajach europejskich. Celem badania jest ustalenie, które obawy dotyczące szczepień są ważniejsze i mają wpływ na poziom szczepień Covid-19. Bada się sześć czynników; trzy z nich dotyczą rządowego systemu podawania szczepionek, pozostałe trzy dotyczą opinii publicznej na temat szczepień przeciwko Covid-19. Analiza prowadzona jest w 22 krajach europejskich. Wynik badania pozwala stwierdzić, że czynniki opinii publicznej w przypadku pandemii odgrywają największą rolę i mają większy wpływ na wskaźnik szczepień.

Słowa kluczowe: Pandemia Covid-19 (koronawirusa), rządowy system podawania szczepionek, opinie publiczne, analiza danych regresyjnych

\section{Introduction}

The Covid-19 pandemic has had a major effect not only on people's life but also on countries' development. In new pandemic conditions researchers focused on studying all aspects of the Covid-19 impact both on human health and on the countries' future development. For the whole world this is a time of great uncertainly. A year ago, everyone thought that emergence of a Covid-19 vaccine would reduce the uncertainly degree. The vaccination is seemed to be the only way to end the pandemic.

Today there are some vaccines that are authorized and recommended in the world to prevent Covid-19. However, the desired effect has not been obtained. On the one hand, there are countries that have no opportunity to purchase vaccines; on the other hand, there are people who do not trust the new vaccine. It leads to the fact that the pandemic is not going to end in the near future and to the continuation of the Covid-19 recession in many countries. Public health correlate and connect with sustainable development strongly. Health of population contributes to economic development through high productive employment and low expenditure on illness care. It is fundamental for sustainable development.

While the Covid-19 vaccination has just begun and it is too early to make conclusion, certain trends in the factors impact are already visible. For example, among European countries Luxemburg with the highest health expenditures has the rate of Covid-19 vaccination four times less than in United Kingdom. Serbia is in the second place after United Kingdom in the number of vaccinated population and spends four times less than United Kingdom on medicine. These contradictions make it necessary to compare and assess factors affecting the vaccination Covid19.

\section{Literature Review}

Different countries have adopted different containment strategies for Covid-19 spread. Learning from each country's experience and applying the best strategies is important. Some researches propose methods to allow direct between-country comparisons. Its results clearly show that comparing num- bers of cases or deaths per 100,000 inhabitants suggests huge differences between countries (Middelburg, Rosendaal, 2020).

Other researchers focus on factor analysis. Most of the papers analyze lifestyle risk factors (smoking, physical inactivity, obesity, and excessive alcohol intake) and their impact on the Covid-19 spread (Hamer et al, 2020).

The next step was to study not only medical side of Covid-19 spread, but also a social. In paper (VeraValdés, 2021) 23 explanatory variables on health, political, and economic factors for 94 countries are considered. It is found out that the higher of trust in medical personnel and in the government a lower number of Covid-19 cases per million inhabitants. With the Covid-19 vaccine invention researchers began to analyze the issues associated with its adoption.

On the one side, vaccine deployment plans and rollout of vaccination has been developed. The main role is assigned to the government (Strategic considerations in preparing for deployment of COVID19 vaccine and vaccination in the WHO European Region, 2021). There are concerns that level of development of the country and patterns of vaccine administration may not be at enough level to stop pandemic.

On the other side, there is an understanding of the fact that vaccination rate also depends on the population's acceptance. There are Covid-19 vaccination studies that prove correlation between belief and attitudes (Fisher et al, 2020), safety concerns (Gadoth et al, 2020) and Covid-19 vaccine acceptance. In paper (Clarke $\mathrm{Ph}$. et al, 2021) study involved 15,536 people from 13 countries. Realizing the importance of public opinion European Commission requested a survey (Public opinion on Covid 19 vaccination in the EU, 2021). Almost the same surveys have been done in many countries (Report to the Orange County COVID-19, 2020).

From here there are two concerns about vaccination come to the fore. The first concern relates to a government vaccine administration, the other one to society rejection.

Aim is to find out which concerns about vaccination are more important and have an impact on the Covid19 vaccination level in European countries. 


\section{Research methodology}

The research measured 2 concerns that have been shown to affect the Covid-19 vaccination level in European countries.

While the one concern is about a government vaccine administration, the other is about a public opinion on Covid-19 vaccination. Each concern includes several factors.

A government vaccine administration depends on economic wealth, progress, and wellbeing. The standard measure of economic wellbeing is gross domestic product (GDP). For today GDP is the world's most powerful statistical indicator of national development and progress (Lepenies, 2016). There are different types of GPD. To compare and assess factors affecting the Covid-19 vaccination level in European countries is better to use GDP for capita, because it takes into account the population of a country without the cost of living that provides reliable statistics for every country.

Obviously, the costs expenditures to Covid-19 vaccination are determined not only by economic, but also by social factors. The other component of vaccine administration is the financial recourses that a government devotes to health care. Since the Covid19 vaccine cannot be purchased by private buyers, government health expenditure is of interest to compare and assess. For data to be more comparable, it is better to use indicator of government health expenditure for capita.

The last factor of the government vaccine administration is the organizational structure of a country's health system which one of the components is immunization. Immunization is a shared responsibility of both government and population (World Health Organization Scientific Advisory Group of Experts, 1998). A country's routine immunization system starts when vaccine is supplied by the manufacturer and ends when it reaches people. To compare and assess the level of the immunization system in European countries it is worth to analyze the childhood vaccines administration.

The other concern of the vaccination level in European countries is about a public opinion on Covid-19 vaccination (Kozlovskyi et al., 2021). On the one hand, people want to protect themselves from Covid19 , on the other hand, there is no confidence in the vaccine safety for health. From here factors can be divided into negative and positive factors affecting the Covid-19 vaccination level in European countries.

According to Survey requested by European Commission (Public opinion on Covid 19 vaccination in the EU, 2021) factors that forms negative attitude can be combined into such groups:

- public authorities are not sufficiently transparent about Covid-19 vaccine;

- Covid-19 vaccine are being developed, tested and authorized too quickly to be safe;
- people can avoid being infected by Covid-19 without being vaccinated.

Positive attitude to Covid-19 vaccination suggests that vaccination is the only way to end the pandemic. Both negative and positive attitude to vaccination resulted in responses according which close to one quarter would like to get vaccinated as soon as possible, slightly less than a third of Europeans would like to do it sometimes in 2021 or later (18\%). About the same number of Europeans are not going to get vaccinated at all (17\%), the rest do not know (13\%). Here the mortality rate for Covid-19 can be added. Covid-19 has spread to approximately 215 countries and territories, in each of which people had died. A high mortality rate for Covid-19 should psychologically influence people to get vaccinated.

A previous analysis of the concerns affecting the vaccination level in European countries can be resulted in the following assumption:

- the higher the GDP for capita, the more opportunities the government has to ensure the high standard of living, including affordable access to quality healthcare;

- the higher the government health expenditure for capita, the more financial resources can be spent on the Covid-19 vaccine purchase;

- the higher the percent of immunized children, the better the immunization system is organized;

- the more who are ready to be vaccinated as soon as possible, the higher the vaccination rate;

- the more who are not ready to be vaccinated at all, the lower the vaccination rate;

- the higher the mortality rate for Covid-19, the higher the vaccination rate.

To test these assumptions statistical methods should be used. Comparison and assessment of factors affecting the Covid-19 vaccination level in European countries assumes to measure the degree to which data move in relation to each other. Regression analysis best suits this goal.

To specify the regression model dependent and independent variables should be defined. As it can be seen from assumptions dependent variable is the vaccination rate in European countries. Independent variables are the GDP for capita, the government health expenditure for capita, the percent of immunized children, DPT (government vaccine administration), the percent of population who are ready to get vaccinated as soon as possible, the percent of population who are not going to get vaccinated, the mortality rate for Covid-19 (public opinion on Covid-19 vaccination).

The impact of independent variables on the vaccination level in European countries should be considered in dynamics, since different countries show different increase in the vaccinated population from week to week.

Thus, the method of regression analysis is used for the assessment of factors affecting the vaccination Covid-19 level in European countries. 


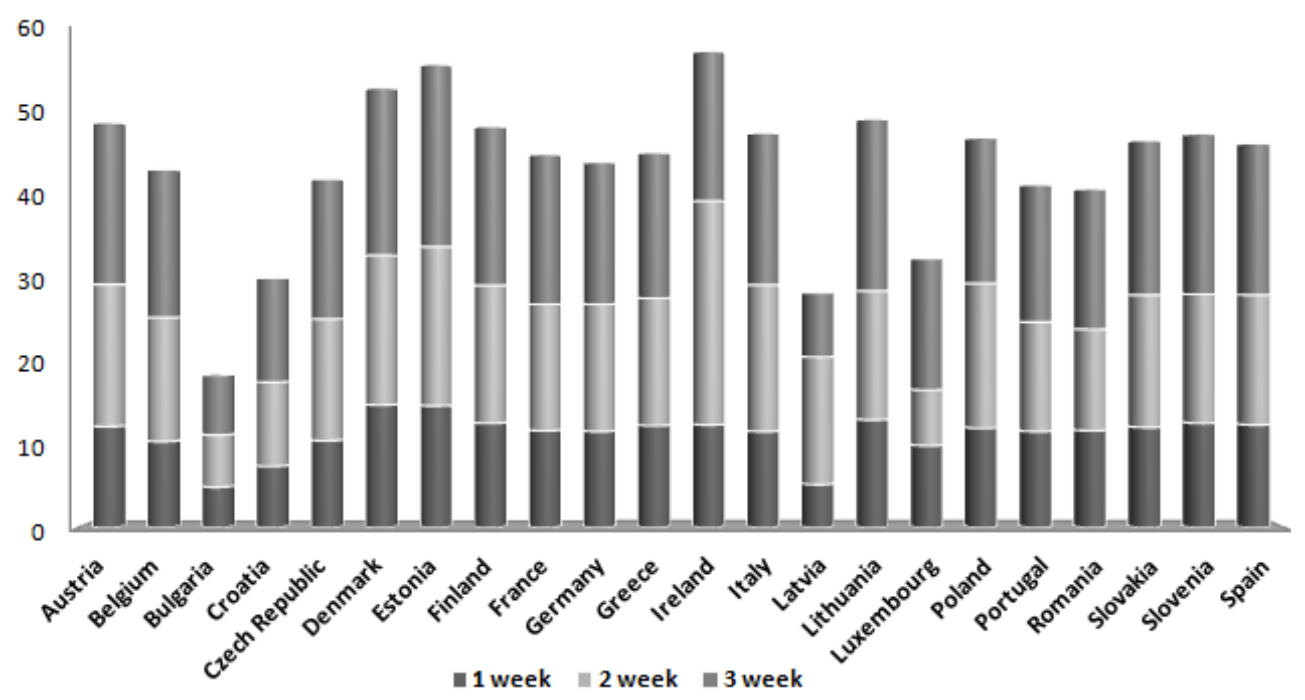

Figure 1. Weekly rate of Covid-19 vaccination, by country (per 100 people), (Statista, 021)

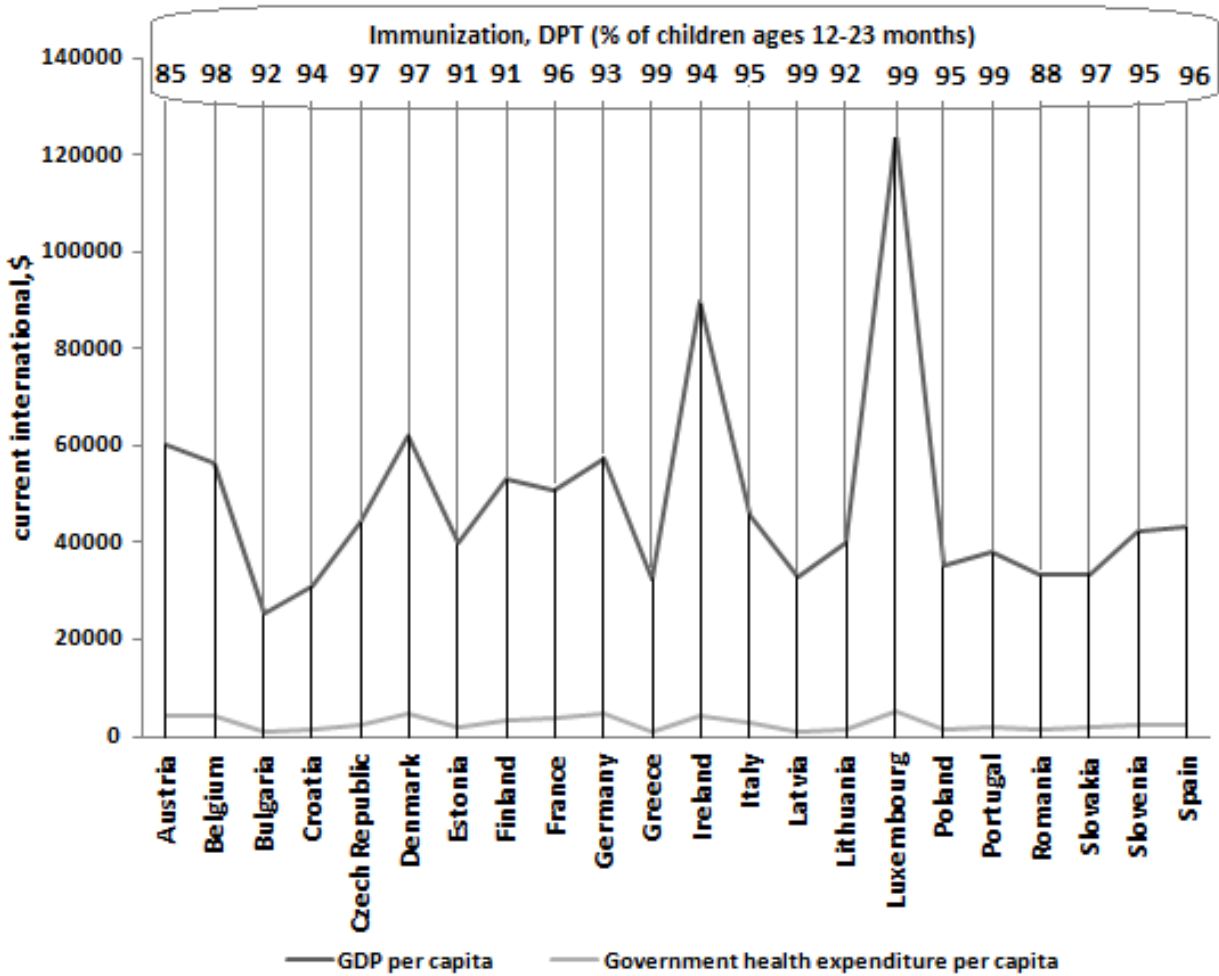

Figure 2. Data for comparison and assessment government vaccine administration factors (Worldometers, 2021)

\section{Results}

For the comparison and assessment of factors affecting the Covid-19 vaccination level were chosen 22 in European countries that took part in the Desk Research Public opinion on Covid-19 vaccination in the $E U$ (2021).

The data for dependent variable consists of the historical weekly number of Covid-19 vaccination doses administrated in Europe as of March 17, March 28, April 4, 2021 per 100 populations (fig.1). Population who had been vaccinated from Covid-19 peaked in Ireland, a little less vaccinated in Estonia and Denmark. Bulgaria, Latvia, and Croatia have the lowest vaccination rates among the countries analyzed.

Data for comparison the government vaccine administration factors were taken from Worldometers databases (fig.2).

The highest GDP for capita is in Denmark, Ireland, and Luxemburg. However, only Denmark is in the top five vaccination's country among European countries. Bulgaria and Croatia have the lowest GDP for capita as well as vaccination rate.

Compared with the other European countries, Denmark, Germany, and Luxemburg have the highest government health expenditure for capita, spending approximately four times more than in Latvia, 
Table 1. A regression analysis result for government vaccine administration factors

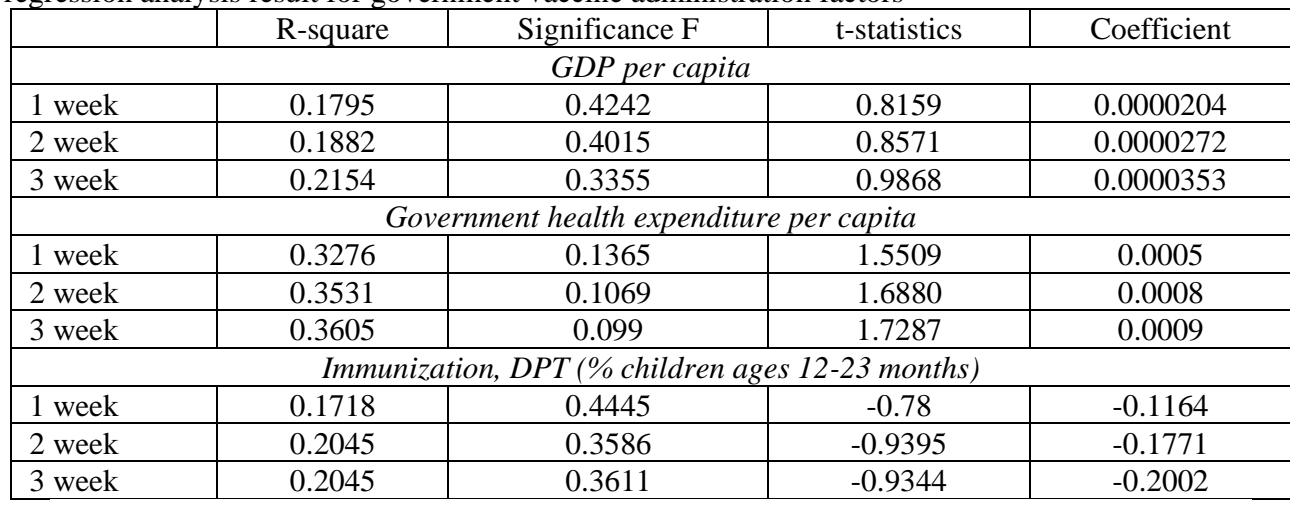

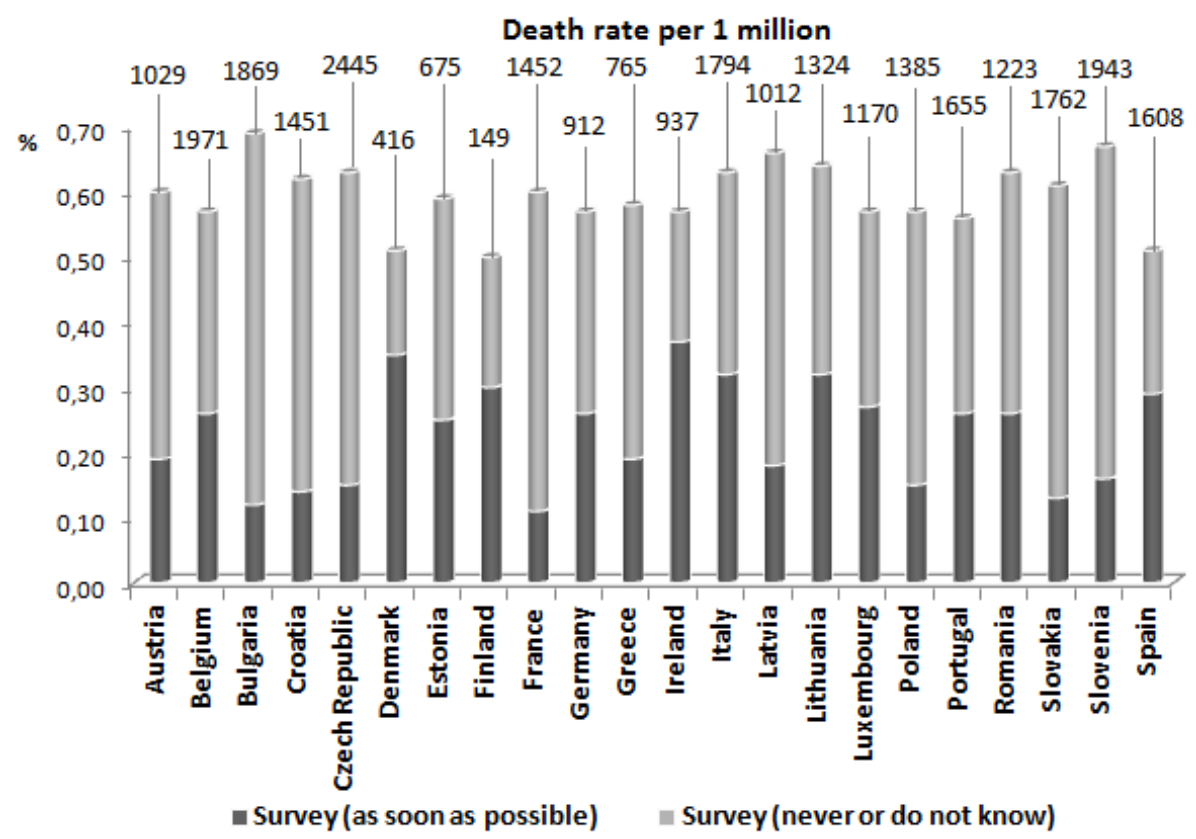

Figure 3. Data for comparison and assessment public opinions factors (World Bank, 2021)

Greece, and Bulgaria that are the lowest spenders. Both Latvia and Bulgaria vaccinate less than $7 \%$ of population based on latest information.

In every European country immunizations to protect against diphtheria, whooping cough and tetanus (DPT immunization) are given to children. DPT vaccine is compulsory, and the number of vaccinated children may indicate the organization of the immunization system. Despite this, the percent of immunized children ages 12-23 months varies significantly from $85 \%$ in Austria to $99 \%$ in Greece, Latvia, Luxemburg, and Portugal. At the same time Latvia and Luxemburg are among the five countries with the lowest Covid-19 vaccination rates.

To run a regression analysis the data for comparison and assessment government vaccine administration factors were tested with a Chi-square test and heteroskedasticity test. The data are truly independent.

A regression analysis was done in Excel using the Regression data analysis tool. The result is displayed in Table 1.
The coefficient of determination (the R-square value in table 1) measures the proportion of variation in the vaccination rate explained by the government vaccine administration factors. The higher correlation's strength is preferred (Kozlovskyi et al., 2020). At first $17.95 \%$ of the vaccination rate variation is explained by the GDP per capita, $32.76 \%$ is explained by the government health expenditure per capita, and $17.18 \%$ is explained by organization of immunization's system. Evert week the impact of the government vaccine administration factors increases.

The value of significance $F$ in table 1 shows if the regression analysis results are reliable. It should be less than 0.05 . For every factor of the government vaccine administration significance $F$ is more than 0.05 . It means that the impact of the government vaccine administration factors should be rejected.

Also, none of the factors of the government vaccine administration have a significant effect on the vaccination rate. To reach this conclusion the value of $t-$ statistics in table 1 was compared with critical value of the student's test of freedom 21 and 5\% significance level. 
Table 2. A regression analysis result for public opinions factors

\begin{tabular}{|c|c|c|c|c|}
\hline & R-square & Significance F & t-statistics & Coefficient \\
\hline \multicolumn{5}{|c|}{ Positive public opinion } \\
\hline 1 week & 0.4767 & 0.0248 & 2.4251 & 15.103 \\
\hline 2 week & 0.4521 & 0.0346 & 2.2668 & 18.208 \\
\hline 3 week & 0.4301 & 0.0456 & 2.1310 & 19.684 \\
\hline \multicolumn{5}{|c|}{ Negative public opinion } \\
\hline 1 week & 0.5731 & 0.0052 & -3.1282 & -12.596 \\
\hline 2 week & 0.5561 & 0.0072 & -2.9914 & -15.53 \\
\hline 3 week & 0.5108 & 0.0151 & -2.6575 & -16.213 \\
\hline \multicolumn{5}{|c|}{ Death rate per 1 million } \\
\hline 1 week & 0.3369 & 0.1251 & -1.6006 & -0.0015 \\
\hline 2 week & 0.2877 & 0.1940 & -1.3438 & -0.00147 \\
\hline 3 week & 0.2221 & 0.3205 & -1.0187 & -0.00145 \\
\hline
\end{tabular}

The mean change of the vaccination rate for one unit of change in the government vaccine administration factors also increase. It can be seen from the regression coefficient in table 1 . The trend in the regression coefficients change is fully consistent with the trend in the R-square value change. So the government vaccine administration factors are becoming to inspire confidence for population.

Comparison and assessment of factors affecting the Covid-19 vaccination level in European countries allows concluding that government vaccine administration factors do not significantly affect vaccination rates.

Data for comparison the public opinions factors were taken from World Bank databases and Survey Public opinion on Covid-19 vaccination in the EU (fig. 3).

In Ireland, Italy, and Lithuania approximately a third of the population want to get vaccinated as soon as possible. In Bulgaria, France, and Slovenia approximately a half of the population are not going to vaccinate or do not have any opinion. The mortality rate for Covid-19 differs and may have an impact on public opinion about vaccination. For example, while in Czech Republic it has reached 2445 death per 1 million, in Finland it is 149 deaths per 1 million.

For assessing factors of the public opinions affecting the vaccination level in European countries regression analysis are run in Excel. The result is displayed in Table 2.

A measure of the correlation's strength (R-square in table 2) between negative public opinion and vaccination rate in European countries is the highest. For the first week it means that $57.31 \%$ of the variation in vaccinated rate can be explained by variations in negative public opinion. R-square is lowest for the factor Death rate per 1 million, but still higher than for government vaccine administration factors. Further the R-square decrease for all public opinions factors.

Since significance $\mathrm{F}$ is less than 0.05 for both negative and positive public opinion factors, results are reliable.

According to t-statistics in table 2 the factors of the negative and positive public opinion have a signifi- cant effect on the vaccination rate in contrast to factor Death rate per 1 million.

The trend in the regression coefficients change is the opposite of the R-square in table 2. It means that despite of the vaccination's result, the population is not apt to change its first opinion.

Comparison and assessment of public opinion factors affecting the Covid-19 vaccination level in European countries allows concluding that negative public opinion affect vaccination rates the most.

\section{Discussion}

While a regression analysis result for government vaccine administration factors shows that none of the factors have a significant effect on the vaccinated rate in European countries, a regression analysis result for public opinions factors, especially for negative public opinion, have an effect.

In the current context of the Covid-19 pandemic, public opinion on this issue has a more significant impact on the vaccination process itself. We can observe such a situation in Israel, where more than 50\% of the population (as of 01.04.2021) received the Pfizer vaccine, but as soon as the question of the quality of this vaccine arose, public opinion began to prevail and the State of Israel suspended the purchase of this vaccine and even the payment for previous supplies. This problem has become unique from the point of view. We have witnessed such a situation when the opinion of society has become more important than the opinion of the state with its health policy, state guarantees and financial instruments and opportunities. A unique situation with vaccination has developed in Ukraine. To stimulate the vaccination process, the state of Ukraine adopted a law that is unique from the economic point of view, which removes liability from vaccine manufacturers in the event of negative consequences of vaccination (Law of Ukraine No.1353-IX, 19.03.2021). Ukraine took responsibility for the negative consequences on itself, but the process of vaccination against this in the country did not accelerate. Ukraine ranks one of the last places in Europe for vaccination against 
Covid-19. All these factors indicate that society needs to be influenced through new instruments. These tools can be both compulsory vaccination and information policy that can guarantee high quality vaccines. Individualistic society is less prone to risk getting vaccination that may be needed to control the pandemic.

On the other hand, as it can be seen the correlation's strength between the factors of government vaccine administration and vaccination rate increases and the factors of public opinion and vaccination rate decreases. Over the time it is likely that factors of government vaccine administration come out on the top. The main criterion by which comparison and assessment of factors affecting the Covid-19 vaccination level is carried out is correlation's strength ( $\mathrm{R}$-square in table 1,2) between factors. Despite the fact that $\mathrm{R}$-square do not show a high correlation, in new pandemic condition it can be used to determine the value of the assumptions being tested and results can become part of any policy discussion.

\section{Conclusion}

As a result of studying the problem of vaccination and the factors that influence this process in European countries, the following conclusions can be drawn (results of regression analysis):

- the GDP for capita has a negligible correlation with the vaccinated rate, its values increases, the reliability of the model is low but it improves;

- the government health expenditure for capita has a low positive correlation with the vaccinated rate, its values increases, the reliability of the model is likely to be high in a few time;

- the immunization system has a lowest correlation with the vaccinated rate, the reliability of the model shows no significant tendency to improve;

- the part of the population who are ready to be vaccinated as soon as possible has a low positive correlation with the vaccinated rate, its values decreases, the reliability of the model is likely to deteriorate;

- the part of the population who are not ready to be vaccinated at all has a moderate negative correlation with the vaccinated rate, its values decreases, the reliability of the model is high;

- the mortality rate for Covid-19 has a negligible correlation with the vaccinated rate, its values decreases, the reliability of the model is not enough.

Comparison and assessment of factors affecting the Covid-19 vaccination level allows concluding that public opinions factors are more important in pandemic and have more impact on the vaccination rate. Regardless of vaccination results public opinions factors are not easy to change. In a few time the government health expenditure for capita is likely to have the greatest impact on the vaccination level in
European countries. Other factors do not have a significant impact.

\section{References}

1. FISHER K., BLOOMSTONE S., WALDER J., CRAWFORD S., FOUAYZI H., MAZOR K., 2020, Attitudes toward a potential SARS-CoV-2 vaccine: a survey of US adults, Annals of Internal Medicine, 2020, 173(12): 964-973.

2. GADOTH A., HALBROOK M., MARTIN BLAIS R., GRAY A., TOBIN N., FERBAS K., RIMOIN A., 2020, Assessment of COVID-19 vaccine acceptance among healthcare workers in Los Angeles, 2020, https://www.medrxiv.org/content/10.1101/ 2020.11.18.20234468v1.full/.

3. HAMER M., KIVIMAKL M., GALE R., BATTY D., 2020, Lifestyle risk factors, inflammatory mechanisms, and COVID-19 hospitalization: A community-based cohort study of 387,109 adults in UK. Brain, Behavior and Immunity, 87: 184-187.

4. KOZLOVSKYI A., BILENKO D., KOZLOVSKYI S., LAVROV R., SKYDAN O., IVANYUTA N., 2020, Determination of the risk-free rate of return on an investment efficiency based on the fractal markets hypothesis, Forum Scientiae Oeconomia, 8(3): 61-72, http://ojs.wsb.edu.pl/index.php/fso/article/vi ew/316/247 (30.X.2020).

5. KOZLOVSKYI S., BILENKO D., KUZHELIEV M., LAVROV R., KOZLOVSKYI V., MAZUR H., TARANYCH A., 2020, The system dynamic model of the labor migrant policy in economic growth affected by COVID-19, Global Journal of Environmental Science and Management, 6(SI): 95-106. DOI: 10.22034/GJESM.2019.06.SI.09.

6. KOZLOVSKYI S., BILENKO D., DLUHOPOLSKYI O., VITVITSKYI S., BONDARENKO O., KORNIICHUK O., 2021, Determinants of COVID19 Death Rate in Europe: Empirical Analysis, Problemy Ekorozwoju/ Problems of sustainable development, 16(1): 17-28.

7. LAW OF UKRAINE, 2021, About modification of article 9-2 of the Law of Ukraine 'About medicines' concerning the state registration of vaccines or other medical immunobiological drugs under the obligation, No.1353-IX, 03/19/2021.

8. LEPENIES P., 2016, The Power of a Single Number: A Political History of GDP, Columbia University Strategy, New York.

9. MIDDELBURG R., ROSENDAAL F., 2020, COVID-19: How to make between-country comparisons, International Journal of Infectious Diseases, 96: 477-481. DOI: 10.1016/j.ijid.2020.05.066.

10. Public Opinion on COVID 19 Vaccination in the EU, 2021, Desk Research on Public Opinion on COVID-19 Vaccination in the EU, European Commission, p. 3-5, https://www.google.com/url?sa=t\& $\mathrm{rct}=\mathrm{j} \& \mathrm{q}=\& \mathrm{esrc}=\mathrm{s} \&$ source $=$ web $\& \mathrm{~cd}=\& \mathrm{ved}=2 \mathrm{ahUK}$ EwjW4umyqf7vAhUSAxAIHYoOCCEQFjAAegQ egQIAxAD\&url=https $\% 3 \mathrm{~A} \% 2 \mathrm{~F} \% 2 \mathrm{Fec}$.europa.eu $\%$ 2Fcommfrontoffice $\% 2$ Fpublicopinion $\% 2$ Findex.cf $\mathrm{m} \%$ 2FResultDoc\%2Fdownload\%2FDocumentKy\% 2F91095\&usg=AOvVaw1wZcal7uHuyDKFta81Z WIM.

11. Public Opinion on Global Rollout of COVID-19 Vaccines, 2021, Clarke Ph. \& Duch R. Nature Med- 
icine, https://www.nature.com/articles/s41591-02101322-9.

12. Report to the Orange County COVID-19, 2020, Vaccine Taskforce, https://occovid19.ochealthinfo.com/ orange-county-covid-19-vaccine-taskforce.

13. STATISTA, 2021, https://www.statista.com/statistics/1196071/covid-19-vaccination-rate-in-europeby-country/ (20.02.2020).

14. VERA-VALDÉS E., 2021, The political risk factors of COVID-19, International Review of Applied Ecconomics, 35: 269-287.

DOI:10.1080/02692171.2020.1866973

15. WORLD HEALTH ORGANIZATION REGIONAL OFFICE FOR EUROPE, 2020, Strategic considerations in preparing for deployment of
COVID19 vaccine and vaccination in the WHO European Region. 21 September 2020. Copenhagen, https://apps.who.int/iris/bitstream/handle/10665/33 5940/WHO-EURO2020-1148-40894-55356-eng. pdf? sequence $=1 \&$ is Allowed $=\mathrm{y}$.

16. WORLD HEALTH ORGANIZATION SCIENTIFIC ADVISORY GROUP OF EXPERTS, 1998, The Children's Vaccine Initiative (CVI) and WHO's global programme for vaccines and immunization (GPV), Weekly Epidemiological Record, 73(37): 281-288.

17. WORLD BANK, 2021, World Bank Indicators, https://data.worldbank.org/indicator (20.02.2020).

18. WORLDOMETER, 2021, https://www.worldometers.info/coronavirus (20.02.2021). 